\title{
The Relationship between Unemployment and Inflation in
}

\section{Sudan: An Empirical Analysis, 1992-2015}

\author{
Badreldin Mohamed Ahmed Abdulrahman ${ }^{1 *}$, Adam Ahmed Soliman Sabil ${ }^{2} \&$ Adil Abdalla Adam \\ Mohamed $^{3}$ \\ ${ }^{1}$ Associate Professor of Economics, University of Zalingei, Sudan \& Al Jouf University, KSA \\ ${ }^{2}$ Associate Professor of Economics, University of Al fashir, Sudan \\ ${ }^{3}$ Lecturer, Department of Economics, University of Zalingei, Sudan \\ *Badreldin Mohamed Ahmed Abdulrahman, E-mail: badreco@gmail.com
}

Received: October 29, 2016 Accepted: Novermber 1, 2016 Online Published: Novermber 2, 2016

doi:10.22158/rem.v1n2p113 URL: http://dx.doi.org/10.22158/rem.v1n2p113

\begin{abstract}
This study investigated from an empirical point of view, the relationship between unemployment and inflation in Sudan during the period 1992-2015. Annual time series data has been used in the analysis to estimate the model for the period under consideration. Data for the study were obtained from central bank of Sudan and central bureau of statistics. Using these data, Granger test is applied to estimate the causal relationship between unemployment and inflation. The results provided that unemployment does not Granger cause Inflation, and inflation dose not Granger cause unemployment. Thus, there is no causality relationship between inflation rates and unemployment rates in Sudan from 1992-2015.
\end{abstract}

\section{Keywords}

unemployment, inflation, time series, relationship, granger, economy

\section{Introduction}

Sudan economy is currently going severe economic crisis. It is experiencing a staggering rate of inflation associated many macroeconomic problems such as high exchange rate, debt overhang, adverse balance of payment rates and high unemployment rates. Unemployment and inflation are two intricately linked economic concepts.

Inflation and unemployment remain burning issues in any economy that is why there have been a number of economists and policy-makers trying to interpret the relationship between the concepts of inflation and unemployment.

The purpose of the paper is to explore the relationship between inflation and unemployment in Sudan over the period 1992-2015.

The rest of the paper is organized as follows: Section two reviews the literature; section three discusses 
the unemployment and inflation in Sudan. The empirical model, results and findings come in section four and five respectively.

\section{Literature Reviews}

According to the ILO guidelines, a person is unemployed if the person is (a) not working, (b) currently available for work, and (c) seeking work. Practical implementation of these guidelines is, however, generally difficult. While employed persons are relatively easily classified in most countries, the issue of classifying non-employed persons as either unemployed or out of the labor force, especially according to criteria (c) is not uncontroversial; see, for instance, $\operatorname{OECD}(1987,1995)$.

Unemployment rate is calculated as following:

Unemployment rate $=\frac{\text { unemployed }}{\text { employed }+ \text { wnemployed }} * 100$

(Supposed that In December 2015, 143060 thousand of US residents were employed and 11,844 thousand were unemployed).

So, Unemployment rate $=11,844 \div(143,060+11,844)=7.64 \%$.

According to economic theory unemployment is classifies into five types:

a. Frictional unemployment,

b. Structural unemployment,

c. Cyclical unemployment,

d. Seasonal unemployment,

e. Disguised unemployment.

In addition to that, there are behavioral unemployment and imported unemployment.

Inflation is a measure of a general increase of the price level in an economy, as represented typically by an inclusive price index, such as the Consumer Price Index in the United States. The term indicates many individual prices rising together rather than one or two isolated prices, such as the price of gasoline in an otherwise calm price environment.

The calculation of inflation rate is as following:

$\left(\left(\mathrm{P}_{\mathrm{t}}-\mathrm{P}_{\mathrm{t}-1}\right) / \mathrm{P}_{\mathrm{t}-1}\right) * 100$

Where $\mathrm{P}_{\mathrm{t}-1}$ is the Starting number and $\mathrm{P}_{\mathrm{t}}$ is the ending number. So if exactly one year ago the Consumer Price Index was 178 and today the CPI is 185 , then the calculations would look like this:

$((185-178) / 178) * 100$ or $(7 / 178) * 100$ or $0.0393 * 100$

Which equals $3.93 \%$.

The causes of inflation are a. Demand pull inflation, b. Cost push inflation, and c. Mixed inflation. And it classify into following standards:

First according to impact standard:

1) Moderate inflation,

2) Creeping inflation, and

Published by SCHOLINK INC. 
3) Galloping inflation.

Second according to source standard:

1) Local or internal inflation, and

2) Import inflation.

Third according to controlling of monetary authorities in prices determinant:

1) Open inflation, and

2) Repressed inflation.

Theoretically inflation is a monetary phenomenon; it may also be demand pull, cost push or imported inflation. The quantity theory of money is used to explain inflation as monetary phenomenon, however, inflation determinants also include; exchange rate, foreign inflation, external deficit, government deficit financing, cost of finance, etc. Therefore inflation is basically affected by various factors that represent economic fundamentals which interact to shape the domestic and foreign imbalances (Abdalla, 2010).

Kiley (2008) examined the common trend in inflation for consumer prices and consumer prices excluding prices of food and energy. Both the Personal Consumption Expenditure (PCE) indexes and the Consumer Price Indexes (CPI). He adopted statistical model employed a bivariate integrated moving average process; his model extends a univariate model that fits the data on inflation very well. The results suggested that the relationship between overall consumer prices, consumer prices excluding the prices of food and energy, and the common trend has changed significantly over time. In the 1970s and early 1980s, movements in overall prices and prices excluding food and energy prices both contained information about the trend; in recent data, the trend is best gauged by focusing solely on prices excluding food and energy prices.

The Phillips curve is often presented in the literature as a dynamic adjustment process of nominal wages to equilibrium and disequilibrium phenomena [cf. Tobin (1982), Laidler and Parkin (1975) and Santomero and Seater (1978)]. Labour market equilibrium is generally considered to be at the "natural rate of unemployment" which, according to Friedman (1968), is "the level that would be ground out by the Walrasian system of general equilibrium equations". Typically, the labour market is not in equilibrium and nominal wage changes will reflect this disequilibrium as well as equilibrium elements such as the steady-state growth of trend productivity and past or expected rates of inflation. In the long run, it is generally assumed that the labour market, like other markets, tends to equilibrium (quoted in Coe).

Hibbs analyzed opinion poll data on the public's relative concern about inflation and unemployment over the period from 1970 to 1980 . He investigated trends and fluctuations in public concern about these problems in the light of recent macroeconomic events. The analysis showed that public opinion responds in a systematic way to macroeconomic developments: high and rising rates of inflation cause upward movements in the public's concern about inflation relative to unemployment, and rising unemployment rates cause upward movements in the public's concern about unemployment relative to inflation. The opinion data indicate that when unemployment is stable, a solid majority of the public 
typically is more concerned about inflation than unemployment if inflation is running higher than $5 \%$ (quoted in Hall).

\section{Unemployment and Inflation in Sudan}

In Sudan, the unemployment rate measures the number of people actively looking for a job as a percentage of the labor force. Unemployment rate in Sudan is increasing for instance; it increased to 19.50 percent in 2014 from 15.90 percent in 2011. Unemployment rate in Sudan averaged 15.83 percent from 1993 until 2014, reaching an all-time high of 19.50 percent in 2014 and a record low of 11.10 percent in 1993 (CBS, 2015).

Abdulrahman (2014) observed that, the inflation rates in Sudan is differing from year to year and from two digit to three digit during the period from 1990-2010 and this is definitely affect the economic performance (measured by GDP). For instant in 1996 the inflation rate is 132.824 and this impacts negatively economic performance that is 404784 and this clear obviously if we compare the rate of inflation and GDP in 1996 with 1995 which is 68.375 and 404973.9 respectively. He analyzed the highest inflation rates in Sudan were reported between 1995-2000 and the lowest rates were reported between 2000-2005 and 2005-2010. The reason behind this variance in the inflation rates depends on economic and political stability as well as interring of oil revenues in economic after 1999.

\section{The Empirical Model}

In this section, we specify the empirical models as following:

$$
\begin{gathered}
\text { Inf }=f(\text { Une }) \\
\text { Une }=f(\text { inf })
\end{gathered}
$$

Where:

Inf is inflation rates.

Une is unemployment rate.

Equation (1) supposes that inflation is cause unemployment, while equation (2) supposes that unemployment causes inflation.

According to Philips curve, there is causal relationship between unemployment and the Rate of Change of Money Wage Rates.

Table 1. Inflation and Unemployment Rates in Sudan, 1992-2015

\begin{tabular}{lll}
\hline Year & Inflation Rate (INF) & Unemployment Rate (UNE) \\
\hline 1992 & 117.624 & 15.4 \\
1993 & 101.305 & 11.1 \\
1994 & 115.478 & 18.5 \\
1995 & 68.375 & 14.6 \\
\hline
\end{tabular}




\begin{tabular}{lll}
\hline 1996 & 132.824 & 16.6 \\
1997 & 46.65 & 18.1 \\
1998 & 17.105 & 18.6 \\
1999 & 15.995 & 15.7 \\
2000 & 8.033 & 15.2 \\
2001 & 4.871 & 15.5 \\
2002 & 8.334 & 15.9 \\
2003 & 7.711 & 15.8 \\
2004 & 8.334 & 16.3 \\
2005 & 7.711 & 17.1 \\
2006 & 8.418 & 17.3 \\
2007 & 8.489 & 19.4 \\
2008 & 7.2 & 20.7 \\
2009 & 7.999 & 20 \\
2010 & 14.284 & 20.3 \\
2011 & 11.257 & 15.9 \\
2012 & 12.978 & 17.1 \\
2013 & 18.9 & 18.8 \\
2014 & 44.4 & 19.5 \\
2015 & 41.9 & 19.7 \\
\hline & &
\end{tabular}

Source: $\mathrm{CBoS} \& \mathrm{CBS}$.

\section{Results and Findings}

Applying Ordinary Least Squares (OLS) technique to the data covering the period (1992-2015) on the variables mentioned above, we estimated equations (1) and (2). The regression results are given in equations (3) and (4) below, where the figures inside the brackets are the t- ratio of the parameters:

$$
\text { Inf }=127.92-5.4 \text { Une }
$$

$R^{2}=0.09$

$\operatorname{Prob}($ F Statistics) $=0.156$

$$
\text { (1.9) (-1.4) }
$$

Equation (3) is statistically insignificant at 5\% level as indicated by F statistics. $\mathrm{R}^{2}$ suggests that $9 \%$ of the variation in inflation explain by unemployment. There are problem of autocorrelation in the model.

$$
\begin{gathered}
\text { Une }=17.78-0.016 \text { Inf } \\
(1.9) \quad(-1.4)
\end{gathered}
$$

$R^{2}=0.09$

Prob $($ F Statistics $)=0.159$

$$
D W=1.44
$$

Equation (4) is statistically not differing than equation (3) except the increasing in F statistic.

By using residual series we obtained the following results:

$$
D \text { (resid05.3) inf }=0.30 \mathrm{D} \text { (resid0.5) }-030 \mathrm{D} \text { (resid0.5une) }
$$


$R 2=0.94 \quad \operatorname{prob}(F$ statistics $)=0.000 \quad D W=1.58$

From equation (4), we observe the reflection of time series data stability of dependent and explanatory variable as indicated by $A D F(\mathrm{ADF}<5 \%$ level).

By using Granger test for equation (1), we obtained the following:

Table 2. Pairwise Granger Causality Tests

\begin{tabular}{lrll}
\hline Null Hypothesis & obs & F-Statistics & Probability \\
\hline$U N E$ does not Granger cause $I N F$ & 22 & 2.74371 & 0.09275 \\
$I N F$ does not Granger cause $U N E$ & & 0.23075 & 0.79639 \\
\hline
\end{tabular}

Source: own calculation.

From above Table we conclude that:

1) Unemployment does not Granger cause Inflation in Sudan during the period from 1992-2015.

2) Inflation dose not Granger cause Unemployment in Sudan during the period from 1992-2015.

So there is no causality relationship between inflation rates and unemployment rates in Sudan from 1992-2015.

\section{Reference}

Abdalla, M. M. (2010). Inflation Determinants in Sudan 1970-2009. The central Bank of Sudan publication, Khartoum, Sudan.

Abdulrahman, B. M. A. (2014). Economic policies and development in Sudan (2000-2013). International Academic Journal of Economics and Finance, 1(3), 1-9.

Abdulrahman, B. M. A. (2014). Inflation and Economic Performance in Sudan: An Analysis Study. Researchjournali's Journal of Economics, 2(3).

Abdulrahman, B. M. A. (2013). Fiscal Policy and Economic Growth in Sudan, 1996-2011. International Journal of Economics, Finance and Management, 2(8).

Byner, D., \& Eric, S. (n.d.). Defining Unemployment in Developing Countries: The Case of Trinidad and Tobago. Working Paper No1/09, Centre for Research in Economic Development and International Trade, University of Nottingham Central Bank of Sudan Reports (CBoS). Various issues.Central Bureau of Statistics in Sudan (CBS).

Coe, D. T. (n.d.). Nominal Wages. The Nature and Wage Flexibility. A manual Book.

Fair, R. C. (n.d.). Inflation and Unemployment in a macro-econometric model. Cowles Foundation for Research in Economics at Yale University.

Hall, E. R. (1982). Inflation: Causes and effects. University of Chicago-Press. Retrieved from http://www.nber.org/books/hall82-1

Kiley, M. T. (2008). Estimating the common trend rate of inflation for consumer prices and consumer 
prices excluding food and energy prices. Working Paper, Finance and Economics Discussion Series Divisions of Research \& Statistics and Monetary Affairs, Federal Reserve Board, Washington, D.C.

Phillips, A. W. (1958). The Relation between Unemployment and the Rate of Change of Money Wage Rates in the United Kingdom, 1861-1957. Economica. http://dx.doi.org/10.1111/j.1468-0335.1958.tb00003.x

\section{Appendix A}

\section{Equation Estimation}

\begin{tabular}{|c|c|c|c|c|}
\hline \multicolumn{5}{|c|}{ Dependent Variable: INF } \\
\hline \multicolumn{5}{|l|}{ Method: Least Squares } \\
\hline \multicolumn{5}{|l|}{ Sample: 19922015} \\
\hline \multicolumn{5}{|c|}{ Included observations: 24} \\
\hline Variable & Coefficient & Std. Error & t-Statistic & Prob. \\
\hline C & 127.9207 & 64.39266 & 1.986573 & 0.0596 \\
\hline UNE & -5.407702 & 3.710897 & -1.457249 & 0.1592 \\
\hline R-squared & 0.088029 & \multicolumn{2}{|c|}{ Mean dependent var } & 34.84063 \\
\hline Adjusted R-squared & 0.046576 & \multicolumn{2}{|c|}{ S.D. dependent var } & 40.92975 \\
\hline S.E. of regression & 39.96521 & \multicolumn{2}{|c|}{ Akaike info criterion } & 10.29355 \\
\hline Sum squared resid & 35138.80 & \multicolumn{2}{|c|}{ Schwarz criterion } & 10.39172 \\
\hline Log likelihood & -121.5226 & \multicolumn{2}{|c|}{ F-statistic } & 2.123576 \\
\hline Durbin-Watson stat & 0.688717 & \multicolumn{2}{|c|}{ Prob(F-statistic) } & 0.159174 \\
\hline
\end{tabular}

\section{Appendix B}

\section{Equation Estimation}

\begin{tabular}{|c|c|c|c|c|}
\hline \multicolumn{5}{|c|}{ Dependent Variable: UNE } \\
\hline \multicolumn{5}{|c|}{ Method: Least Squares } \\
\hline \multicolumn{5}{|l|}{ Sample: 19922015} \\
\hline \multicolumn{5}{|c|}{ Included observations: 24} \\
\hline Variable & Coefficient & Std. Error & t-Statistic & Prob. \\
\hline $\mathrm{C}$ & 17.77965 & 0.593131 & 29.97590 & 0.0000 \\
\hline INF & -0.016278 & 0.011171 & -1.457249 & 0.1592 \\
\hline R-squared & 0.088029 & \multicolumn{2}{|c|}{ Mean dependent var } & 17.21250 \\
\hline Adjusted R-squared & 0.046576 & \multicolumn{2}{|c|}{ S.D. dependent var } & 2.245636 \\
\hline S.E. of regression & 2.192716 & \multicolumn{2}{|c|}{ Akaike info criterion } & 4.487814 \\
\hline Sum squared resid & 105.7761 & \multicolumn{2}{|c|}{ Schwarz criterion } & 4.585986 \\
\hline
\end{tabular}




\begin{tabular}{|l|l|l|l|}
\hline Log likelihood & -51.85377 & F-statistic & 2.123576 \\
\hline Durbin-Watson stat & 1.444237 & Prob(F-statistic) & 0.159174 \\
\hline
\end{tabular}

\section{Appendix C}

\section{Results in Level}

\begin{tabular}{|c|c|c|c|c|}
\hline \multirow[t]{3}{*}{ ADF Test Statistic } & -1.498218 & $1 \%$ & Critical Value* & -3.7667 \\
\hline & & $5 \%$ & Critical Value & -3.0038 \\
\hline & & \multicolumn{2}{|c|}{$10 \%$ Critical Value } & -2.6417 \\
\hline \multicolumn{5}{|c|}{ *MacKinnon critical values for rejection of hypothesis of a unit root. } \\
\hline \multicolumn{5}{|c|}{ Augmented Dickey-Fuller Test Equation } \\
\hline \multicolumn{5}{|c|}{ Dependent Variable: D(RESID05) } \\
\hline \multicolumn{5}{|c|}{ Method: Least Squares } \\
\hline \multicolumn{5}{|c|}{ Sample(adjusted): 19942015} \\
\hline \multicolumn{5}{|c|}{ Included observations: 22 after adjusting endpoints } \\
\hline Variable & Coefficient & Std. Error & t-Statistic & Prob. \\
\hline RESID05(-1) & -0.246100 & 0.164262 & -1.498218 & 0.1505 \\
\hline D(RESID05(-1)) & -0.484628 & 0.180245 & -2.688712 & 0.0145 \\
\hline $\mathrm{C}$ & -2.756764 & 5.608548 & -0.491529 & 0.6287 \\
\hline R-squared & 0.427277 & \multicolumn{2}{|c|}{ Mean dependent var } & -0.586307 \\
\hline Adjusted R-squared & 0.366990 & \multicolumn{2}{|c|}{ S.D. dependent var } & 32.82506 \\
\hline S.E. of regression & 26.11624 & \multicolumn{2}{|c|}{ Akaike info criterion } & 9.489115 \\
\hline Sum squared resid & 12959.10 & \multicolumn{2}{|c|}{ Schwarz criterion } & 9.637894 \\
\hline Log likelihood & -101.3803 & \multicolumn{2}{|c|}{ F-statistic } & 7.087428 \\
\hline Durbin-Watson stat & 1.406386 & \multicolumn{2}{|c|}{ Prob(F-statistic) } & 0.005017 \\
\hline
\end{tabular}

\section{Appendix D}

\section{Results in First Different}

\begin{tabular}{|l|l|ll|l|}
\hline ADF Test Statistic & -2.729086 & $1 \%$ & Critical Value* & -3.7856 \\
\hline & & $5 \%$ & Critical Value & -3.0114 \\
\hline & $10 \%$ Critical Value & -2.6457 \\
\hline *MacKinnon critical values for rejection of hypothesis of a unit root. \\
\hline Augmented Dickey-Fuller Test Equation \\
\hline Dependent Variable: D(RESID05,2) \\
\hline Method: Least Squares \\
\hline Sample(adjusted): 19952015 \\
\hline Included observations: 21 after adjusting endpoints \\
\hline
\end{tabular}




\begin{tabular}{|l|l|l|l|l|}
\hline Variable & Coefficient & Std. Error & t-Statistic & Prob. \\
\hline D(RESID05(-1)) & -1.062985 & 0.389502 & -2.729086 & 0.0138 \\
\hline D(RESID05(-1),2) & -0.285138 & 0.215962 & -1.320317 & 0.2033 \\
\hline C & -2.294189 & 5.728526 & -0.400485 & 0.6935 \\
\hline R-squared & 0.816263 & \multicolumn{2}{|c|}{ Mean dependent var } & -2.648022 \\
\hline Adjusted R-squared & 0.795848 & S.D. dependent var & 57.37197 \\
\hline S.E. of regression & 25.92247 & Akaike info criterion & 9.479661 \\
\hline Sum squared resid & 12095.54 & \multicolumn{2}{|c|}{ Schwarz criterion } & 9.628878 \\
\hline Log likelihood & -96.53644 & \multicolumn{2}{|c|}{ F-statistic } & 39.98316 \\
\hline Durbin-Watson stat & 1.704386 & Prob(F-statistic) & 0.000000 \\
\hline
\end{tabular}

\section{Appendix E}

\section{Results in Second Different}

\begin{tabular}{|c|c|c|c|c|}
\hline \multirow[t]{3}{*}{ ADF Test Statistic } & -5.801158 & $1 \%$ & Critical Value* & -3.8067 \\
\hline & & $5 \%$ & Critical Value & -3.0199 \\
\hline & & \multicolumn{2}{|c|}{$10 \%$ Critical Value } & -2.6502 \\
\hline \multicolumn{5}{|c|}{ *MacKinnon critical values for rejection of hypothesis of a unit root. } \\
\hline \multicolumn{5}{|c|}{ Augmented Dickey-Fuller Test Equation } \\
\hline \multicolumn{5}{|c|}{ Dependent Variable: D(RESID05,3) } \\
\hline \multicolumn{5}{|c|}{ Method: Least Squares } \\
\hline \multicolumn{5}{|c|}{ Sample(adjusted): 19962015} \\
\hline \multicolumn{5}{|c|}{ Included observations: 20 after adjusting endpoints } \\
\hline Variable & Coefficient & Std. Error & t-Statistic & Prob. \\
\hline D(RESID05(-1),2) & -2.315253 & 0.399102 & -5.801158 & 0.0000 \\
\hline D(RESID05(-1),3) & 0.296894 & 0.200479 & 1.480922 & 0.1569 \\
\hline $\mathrm{C}$ & 2.882451 & 6.171180 & 0.467083 & 0.6464 \\
\hline R-squared & 0.939346 & \multicolumn{2}{|c|}{ Mean dependent var } & 4.583959 \\
\hline Adjusted R-squared & 0.932211 & \multicolumn{2}{|c|}{ S.D. dependent var } & 105.8318 \\
\hline S.E. of regression & 27.55479 & \multicolumn{2}{|c|}{ Akaike info criterion } & 9.607711 \\
\hline Sum squared resid & 12907.53 & \multicolumn{2}{|c|}{ Schwarz criterion } & 9.757071 \\
\hline Log likelihood & -93.07711 & \multicolumn{2}{|c|}{ F-statistic } & 131.6400 \\
\hline Durbin-Watson stat & 1.577864 & \multicolumn{2}{|c|}{ Prob(F-statistic) } & 0.000000 \\
\hline
\end{tabular}




\section{Appendix F}

\section{Granger Tests}

Pairwise Granger Causality Tests

Sample: 19922015

Lags: 2

\begin{tabular}{|l|l|l|c|}
\hline Null Hypothesis: & Obs & F-Statistic & Probability \\
\hline UNE does not Granger Cause INF & 22 & 2.74371 & 0.09275 \\
\hline INF does not Granger Cause UNE & & 0.23075 & 0.79639 \\
\hline
\end{tabular}

